\title{
AHP and GIS-Based Site Selection for a Sanitary Landfill: Case of Settat Province, Morocco
}

\author{
Ghizlane Benezzine ${ }^{1 *}$, Abdeljalil Zouhri', Yahya Koulali \\ 1 Hassan First University of Settat, Faculty of Sciences and Techniques, Applied Chemistry and Environment \\ Laboratory, Settat, Morocco \\ 2 Hassan First University of Settat, Faculty of Sciences and Techniques, Laboratory of Biochemistry, \\ Neurosciences, Natural Resources and Environment, Settat, Morocco \\ * Corresponding author's email: g.benezzine@uhp.ac.ma
}

\begin{abstract}
In Morocco, solid household waste is often disposed of in open air in unsuitable sites, causing adverse effects on humans and the environment. In the province of Settat, there are eight uncontrolled landfills. The present study aimed to determine the most suitable sites from an environmental and economic point of view to ensure good management on a regional scale. The investigation involved a combination of a multi-criteria method (the AHP analytical hierarchy process) and a GIS geographic information system (ArcGIS) with ten criteria: distance from the ground water, water surfaces, drilling, settlements, forests, roads, highway, land use, slope, and elevation. The suitability map showed that about $18.5 \%$ of the study area is suitable for installing a sanitary landfill.
\end{abstract}

Keywords: Sanitary landfill, Household Solid Waste Management, Geographic Information System, Analytical Hierarchy Process, Province of Settat, Morocco.

\section{INTRODUCTION}

Morocco has shown great interest in sustainable development and environmental protection by developing several laws and programs. In the province of Settat, municipalities or delegated companies collect and deposit solid household waste in uncontrolled landfills near effluents or agglomerations. Therefore, waste management is a national and provincial challenge that starts with the location of an adequate area that complies with the Moroccan standards, thus minimizing the negative impacts on public health and the environment. Given its effectiveness and simplicity, a combination of multi-criteria decision analysis (MCA) and geographic information systems (GIS) was used in this work to select appropriate sites. Thomas Saaty invented the concept of the analytical hierarchy process in 1990 (Saaty, 1990). The AHP method is a widely used tool. It aims to facilitate the work by splitting several variants, analyzing them separately in a comparative manner, thus allowing the user to make the most appropriate choice (Anane et al., 2008; Ajibade et al., 2019; Ahmed et al., 2021; Abad, n.d.). Geographic Information Systems (GIS) perform overlay operations, buffer and having the ability to manage several spatial data from various sources - create databases, retrieve, digitize, analyze, store and present data in several forms (Ghobadi et al., 2017). Finally, a landfill site suitability map was obtained and analyzed to help managers choose the common landfill site in the Settat province and waste transfer centers for the Ben ahmed and El brouj circle.

\section{Study area}

The province of Settat is part of the Casablanca-Settat region, consisting of 3 circles; Settat, Ben Ahmed, and El Brouj (Fig. 1). It is on an area of $7220 \mathrm{~km}^{2}$ with 634,196 inhabitants in 2014, according to the last General Census of Population and Housing (RGPH); this population generates 


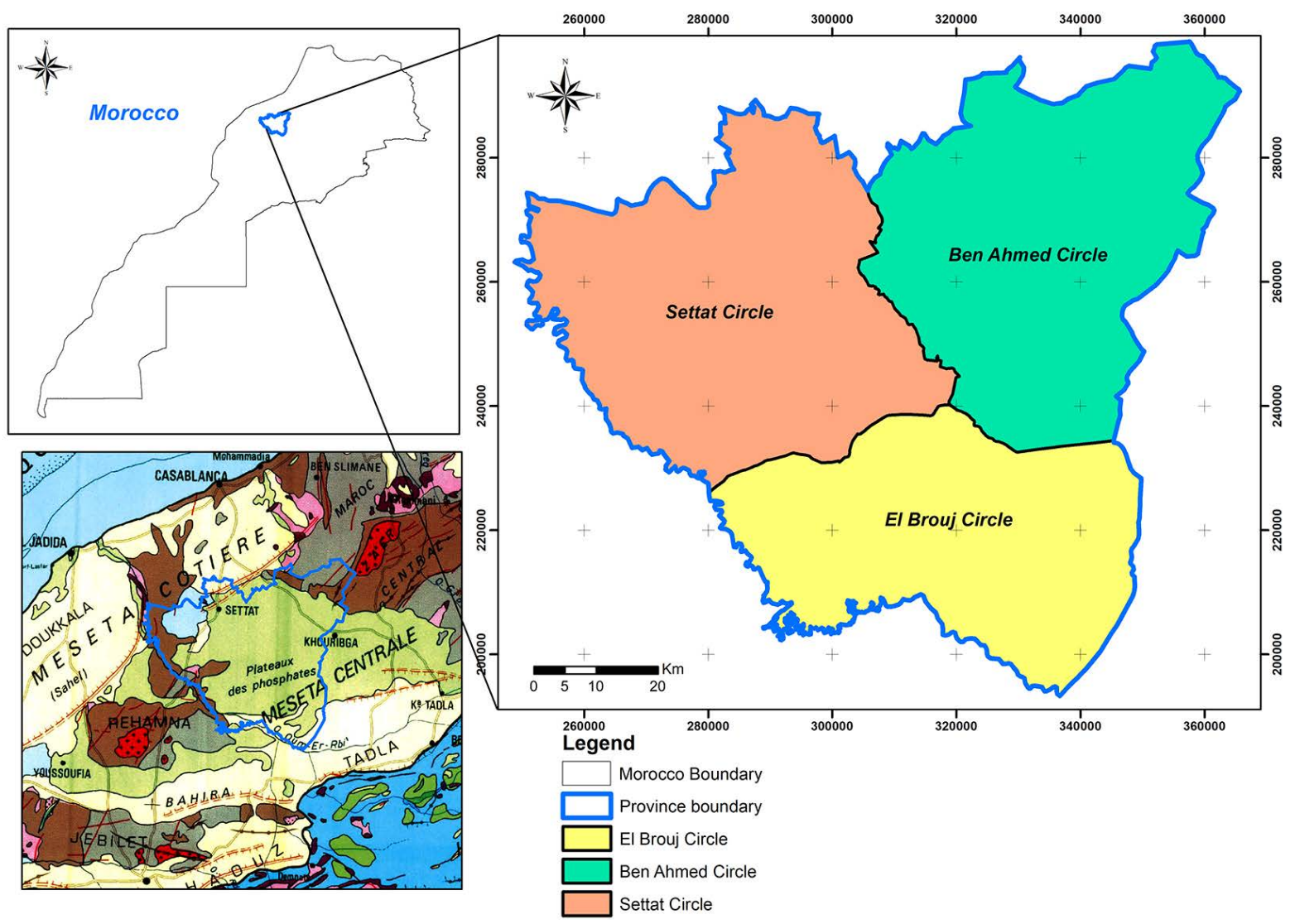

Figure 1. Map of Settat province

a quantity of solid household waste equal to 387 tons per day. The province of Settat belongs to the structural area of the Moroccan Central Meseta. It is located at the overlap of the geological units of the Rehamna massif and the phosphate plateau (Benezzine et al., 2021).

\section{Methodology}

The selection of a better site for a sanitary landfill and the collection and transfer centers of household solid waste in the province of Settat were achieved by integrating GIS through ArcGIS

Table 1. Buffer distances for each criterion (Moroccan Department of the Environment)

\begin{tabular}{|l|c|}
\hline \multicolumn{1}{|c|}{ Criteria } & Buffer distance $(\mathrm{m})$ \\
\hline Settlement & 500 \\
\hline High way & 500 \\
\hline Roads & 300 \\
\hline Cultivated land & 300 \\
\hline Forest & 300 \\
\hline Drilling & 500 \\
\hline Water bodies & 500 \\
\hline Ground water & 500 \\
\hline
\end{tabular}

software and the process of multi-criteria decision analysis AHP. During the establishment of the thematic maps, a buffer zone was assigned to each criterion. This zone is different from one theme to another, depending on the importance of the criterion. The choice of the safety radius was extracted from the Guide for the Pre-Selection of Sites for Controlled Landfills of Household Waste established by the Moroccan Department of the Environment (Table 1). The data was collected from government institutions and various online portals.

The method used in this work is as follows (Figure 2):

1) Identify the study area (Province of Settat).

2) Collect the data, evaluate the criteria and sub-criteria for the operation (AHP) using the Excel software.

3) Carry out several matrices, obtain the weights for each criterion and verify the results.

4) Calculate the indices to verify the consistency of the results of the decision-making process.

5) Reclassify the layers by the values of the sub-criteria.

6) Prepare the data and maps needed to create the GIS database in a standard coordinate system.

7) Classify the layers with distance values by the 
Euclidean distance tool in ArcGIS.

8) Classify layers by sub-criteria values.

9) Weight and analyze the layers in the GIS environment to determine the most appropriate areas by the Overlay weight tool.

10) Select suitable locations for the sanitary landfill and the two collection and transfer centers.

The data collection involved the following:

- Groundwater, surface water and drilling were obtained from the hydraulic basin agencies of Bouregreg-Chaouia and Oum Rbia, which share the territory of Settat Province.

- The road network, residential areas and forest maps were digitized from 1:50,000 topographic maps acquired from the Settat urban agency and satellite images from the USGS site of Esri https://earthexplorer.usgs.gov/

- The land use map was prepared from USGS Esri (Landsat 8), the images were obtained, imported into Arcgis, georeferenced, classified using the maximum likelihood supervised classification method. Six classes were identified: cultivated and uncultivated agriculture, forests, settlements, water bodies and bare soil.

- The slopes and elevations were obtained via the Digital Elevation Model (DEM) available on USGS - United States Geological Survey (https:// www.usgs.gov) using several tools in ArcGIS.

- Location of existing landfills along X, Y was taken from a previous study (Benezzine et al., 2021).

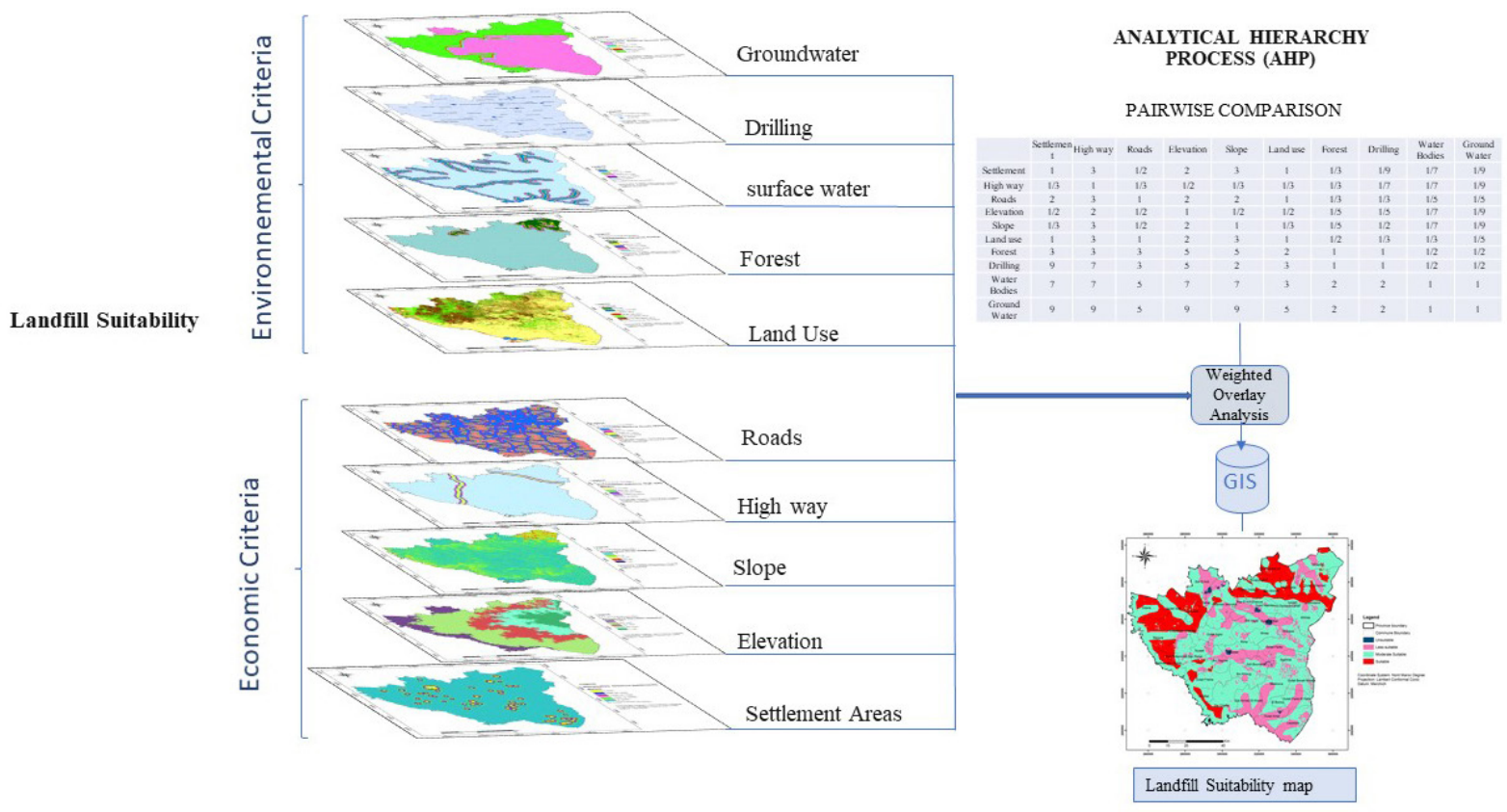

Figure 2. Study methodology

Table 2. Pairwise comparison scale in AHP (Saaty, 1990)

\begin{tabular}{|c|l|l|}
\hline $\begin{array}{c}\text { Intensity of } \\
\text { importance }\end{array}$ & \multicolumn{1}{|c|}{ Definition explanation } & \multicolumn{1}{c|}{ Explanation } \\
\hline 1 & Equal importance & Two attributes preferred equally \\
\hline 2 & Weak or slight & Judgement indicates weak favoring of one attribute over another \\
\hline 3 & Moderate importance & Judgement slightly favored one element over the another \\
\hline 4 & Moderate plus & Judgement moderately favored one element over the another \\
\hline 5 & Strong importance & Judgement strongly favored one element over the another \\
\hline 6 & Strong plus & $\begin{array}{l}\text { Judgement slightly more than strongly favored one element over } \\
\text { the another }\end{array}$ \\
\hline 7 & Very strong or demonstrated importance & Judgement very strongly favored one over the another \\
\hline 8 & Very very strong & Judgement very. very strongly favored one over the another \\
\hline 9 & Extreme importance & Extreme preference of one attribute over the another \\
\hline
\end{tabular}


The integration of AHP and GIS creates an advantageous method that manages the time and cost of decision making, reduces errors, and increases selection accuracy (Donevska et al., 2012; Kebede et al., 2021). This approach has been widely used in several landfill site selection studies (Gbanie et al., 2013; Ghobadi et al., 2017; Yildirim et al., 2018; Ajibade et al., 2019; Ahmed et al., 2021; Ait Errouhi et al., 2021). In the AHP method, the relative importance between two criteria is measured according to a numerical scale of 1 to 9 given by Saaty (Saaty, 1990) (Table 2). The weight of each criterion is calculated based on pairwise comparisons of the different criteria (Table 3) (Chabuk et al., 2016; Ahmed et al., 2021). The criterion is more important if its weight is higher (Table 3). Finally, AHP combines the weights and scores, resulting in a final score for each alternative and a result. The final score for a given a choice is a weighted sum of the scores for all criteria (Table 4). AHP also provides a valuable technique for checking the consistency of results in the decision-making process. This consistency in decisions is measured by evaluating the term consistency ratio (CR), which is the ratio of the consistency index (CI) to the random index (RI) that varies with the number of criteria (Table 5) (Langa et al., 2021; Majid and Mir, 2021).

$$
C R=\frac{C I}{R I}
$$

The consistency index CI is calculated from the pairwise comparison matrix (Gbanie et al., 2013).

$$
C I=\frac{(\lambda \max -\mathrm{n})}{(\mathrm{n}-1)}
$$

where: $\lambda$ max is a special value and $n$ is the number of parameters (Sisay et al., 2021).

CI and RI are calculated from the pairwise comparison matrix (Mahmood et al., 2021; Mortazavi Chamchali et al., 2021). For the matrix to be consistent, the CR must be less than $0.1(10 \%)$ (Saaty, 1980), which is the case in this study $\mathrm{CR}=0.074$ (7.4\%).

\section{RESULTS AND DISCUSSION}

The landfill suitability map was identified using several criteria and sub criteria. The thematic maps of the selected criteria and their buffer zones have been made according to Moroccan standards:

- Groundwater (Figure 3). There are three aquifers in the Province of Settat; the Tadla aquifer, which covers most of the south, the Khemisset Chaouia aquifer adjoins it to the west, and the Berrechid aquifer. It is crucial to locate the landfill away from the groundwater to preserve it. A classification of the surface with the subcriteria was made, considering that the distances lower than $500 \mathrm{~m}$ are inappropriate zones. In contrast, distances higher than $2000 \mathrm{~m}$ are more appropriate zones.

- Drilling (Figure 4). There are several drillings in the province; for this purpose, a distance greater than $2000 \mathrm{~m}$ is the most appropriate (evaluated as 9), while the closest distances to the drillings of less than $500 \mathrm{~m}$ are unacceptable (noted as 1).

- Surface water (Figure 5). Landfills should not be located near surface water because of leachate and toxic gases (Ali et al., 2021). There

Table 3. Pairwise comparison for the main criteria used in this study

\begin{tabular}{|l|c|c|c|c|c|c|c|c|c|c|}
\hline \multicolumn{1}{|c|}{ Criteria } & Settlement & High way & Roads & Elevation & Slope & Land use & Forest & Drilling & $\begin{array}{c}\text { Water } \\
\text { bodies }\end{array}$ & $\begin{array}{c}\text { Ground } \\
\text { water }\end{array}$ \\
\hline Settlement & 1 & 3 & $1 / 2$ & 2 & 3 & 1 & $1 / 3$ & $1 / 9$ & $1 / 7$ & $1 / 9$ \\
\hline High way & $1 / 3$ & 1 & $1 / 3$ & $1 / 2$ & $1 / 3$ & $1 / 3$ & $1 / 3$ & $1 / 7$ & $1 / 7$ & $1 / 9$ \\
\hline Roads & 2 & 3 & 1 & 2 & 2 & 1 & $1 / 3$ & $1 / 3$ & $1 / 5$ & $1 / 5$ \\
\hline Elevation & $1 / 2$ & 2 & $1 / 2$ & 1 & $1 / 2$ & $1 / 2$ & $1 / 5$ & $1 / 5$ & $1 / 7$ & $1 / 9$ \\
\hline Slope & $1 / 3$ & 3 & $1 / 2$ & 2 & 1 & $1 / 3$ & $1 / 5$ & $1 / 2$ & $1 / 7$ & $1 / 9$ \\
\hline Land use & 1 & 3 & 1 & 2 & 3 & 1 & $1 / 2$ & $1 / 3$ & $1 / 3$ & $1 / 5$ \\
\hline Forest & 3 & 3 & 3 & 5 & 5 & 2 & 1 & 1 & $1 / 2$ & $1 / 2$ \\
\hline Drilling & 9 & 7 & 3 & 5 & 2 & 3 & 1 & 1 & $1 / 2$ & $1 / 2$ \\
\hline Water bodies & 7 & 7 & 5 & 7 & 7 & 3 & 2 & 2 & 1 & 1 \\
\hline Ground water & 9 & 9 & 5 & 9 & 9 & 5 & 2 & 2 & 1 & 1 \\
\hline
\end{tabular}


Table 4. Weight of criteria and sub-criteria $\left(\lambda_{\max }=11, \mathrm{CI}=0.11, \mathrm{RI}=1.49\right.$ and $\left.\mathrm{CR}=0.074<0.1\right)$

\begin{tabular}{|c|c|c|c|c|c|}
\hline Main criteria & Weight & Sub criteria & Weight & Classes & Score \\
\hline \multirow{25}{*}{ Economic criteria } & \multirow{25}{*}{0.19} & \multirow{5}{*}{ Settlement } & \multirow{5}{*}{0.05} & $d<500$ & 1 \\
\hline & & & & $500<d<1000$ & 3 \\
\hline & & & & $1000<d<1500$ & 7 \\
\hline & & & & $1500<d<2000$ & 9 \\
\hline & & & & $d>2000$ & 1 \\
\hline & & \multirow{5}{*}{ High way } & \multirow{5}{*}{0.02} & $d<500$ & 1 \\
\hline & & & & $500<d<1000$ & 3 \\
\hline & & & & $1000<d<1500$ & 5 \\
\hline & & & & $1500<d<2000$ & 7 \\
\hline & & & & $d>2000$ & 9 \\
\hline & & \multirow{5}{*}{ Roads } & \multirow{5}{*}{0.05} & $d<300$ & 9 \\
\hline & & & & $300<d<600$ & 7 \\
\hline & & & & $600<d<900$ & 5 \\
\hline & & & & $900<d<1200$ & 3 \\
\hline & & & & $d>1200$ & 1 \\
\hline & & \multirow{5}{*}{ Elevation } & \multirow{5}{*}{0.03} & $<300$ & 9 \\
\hline & & & & $301-500$ & 5 \\
\hline & & & & $501-600$ & 3 \\
\hline & & & & $601-700$ & 1 \\
\hline & & & & $>700$ & 1 \\
\hline & & \multirow{5}{*}{ Slope } & \multirow{5}{*}{0.04} & 0.05 & 9 \\
\hline & & & & $5-10 \%$ & 5 \\
\hline & & & & $10-20 \%$ & 3 \\
\hline & & & & $20-30 \%$ & 0 \\
\hline & & & & $>30 \%$ & 0 \\
\hline \multirow{26}{*}{ Environmental criteria } & \multirow{26}{*}{0.81} & \multirow{6}{*}{ Land use } & \multirow{6}{*}{0.06} & Forest & 0 \\
\hline & & & & Water bodies & 0 \\
\hline & & & & Bare land & 9 \\
\hline & & & & Built up Land & 3 \\
\hline & & & & cultivated Land & 1 \\
\hline & & & & Uncultivated Land & 2 \\
\hline & & \multirow{5}{*}{ Forest } & \multirow{5}{*}{0.12} & $d<300$ & 1 \\
\hline & & & & $300<d<600$ & 3 \\
\hline & & & & $600<d<900$ & 5 \\
\hline & & & & $900<d<1200$ & 7 \\
\hline & & & & $d>1200$ & 9 \\
\hline & & \multirow{5}{*}{ Drilling } & \multirow{5}{*}{0.15} & $d<500$ & 1 \\
\hline & & & & $500<d<1000$ & 3 \\
\hline & & & & $1000<d<1500$ & 5 \\
\hline & & & & $1500<d<2000$ & 7 \\
\hline & & & & $d>2000$ & 9 \\
\hline & & & & $d<500$ & 0 \\
\hline & & & & $500<d<1000$ & 1 \\
\hline & & Water bodies & 0.22 & $1000<d<1500$ & 3 \\
\hline & & & & $1500<d<2000$ & 5 \\
\hline & & & & $d>2000$ & 7 \\
\hline & & & & $d<500$ & 0 \\
\hline & & & & $500<d<1000$ & 1 \\
\hline & & Ground water & 0.26 & $1000<d<1500$ & 3 \\
\hline & & & & $1500<d<2000$ & 5 \\
\hline & & & & $d>2000$ & 9 \\
\hline
\end{tabular}


Table 5. RI values for different matrix sizes (Ghobadi et al., 2017)

\begin{tabular}{|c|c|c|c|c|c|c|c|c|c|c|c|c|c|c|c|}
\hline $\mathrm{n}$ & 1 & 2 & 3 & 4 & 5 & 6 & 7 & 8 & 9 & 10 & 11 & 12 & 13 & 14 & 15 \\
\hline $\mathrm{RI}$ & 0 & 0 & 0.58 & 0.90 & 0.12 & 1.24 & 1.32 & 1.41 & 1.45 & 1.49 & 1.51 & 1.48 & 1.56 & 1.57 & 1.59 \\
\hline
\end{tabular}

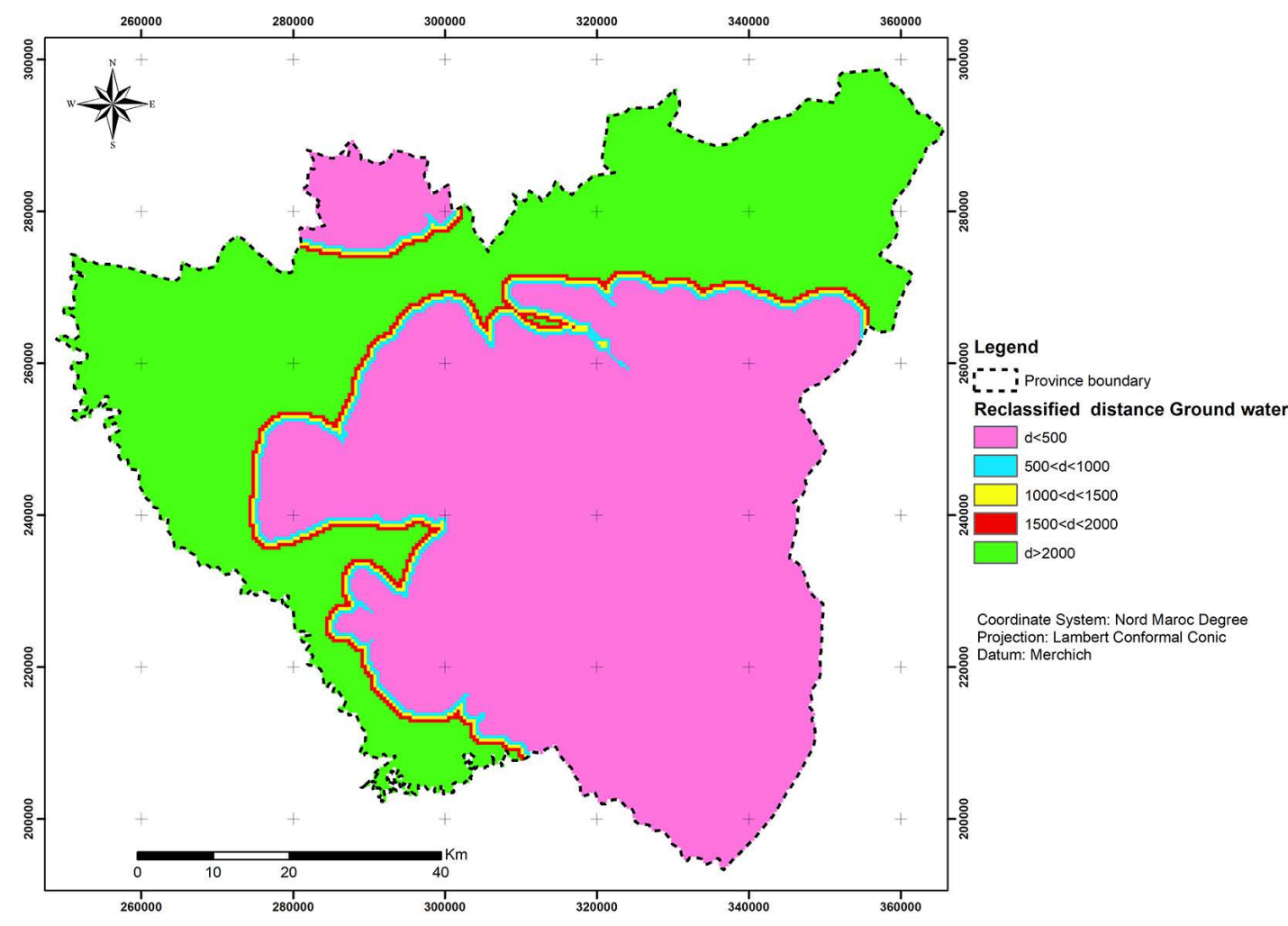

Figure 3. Map of groundwater

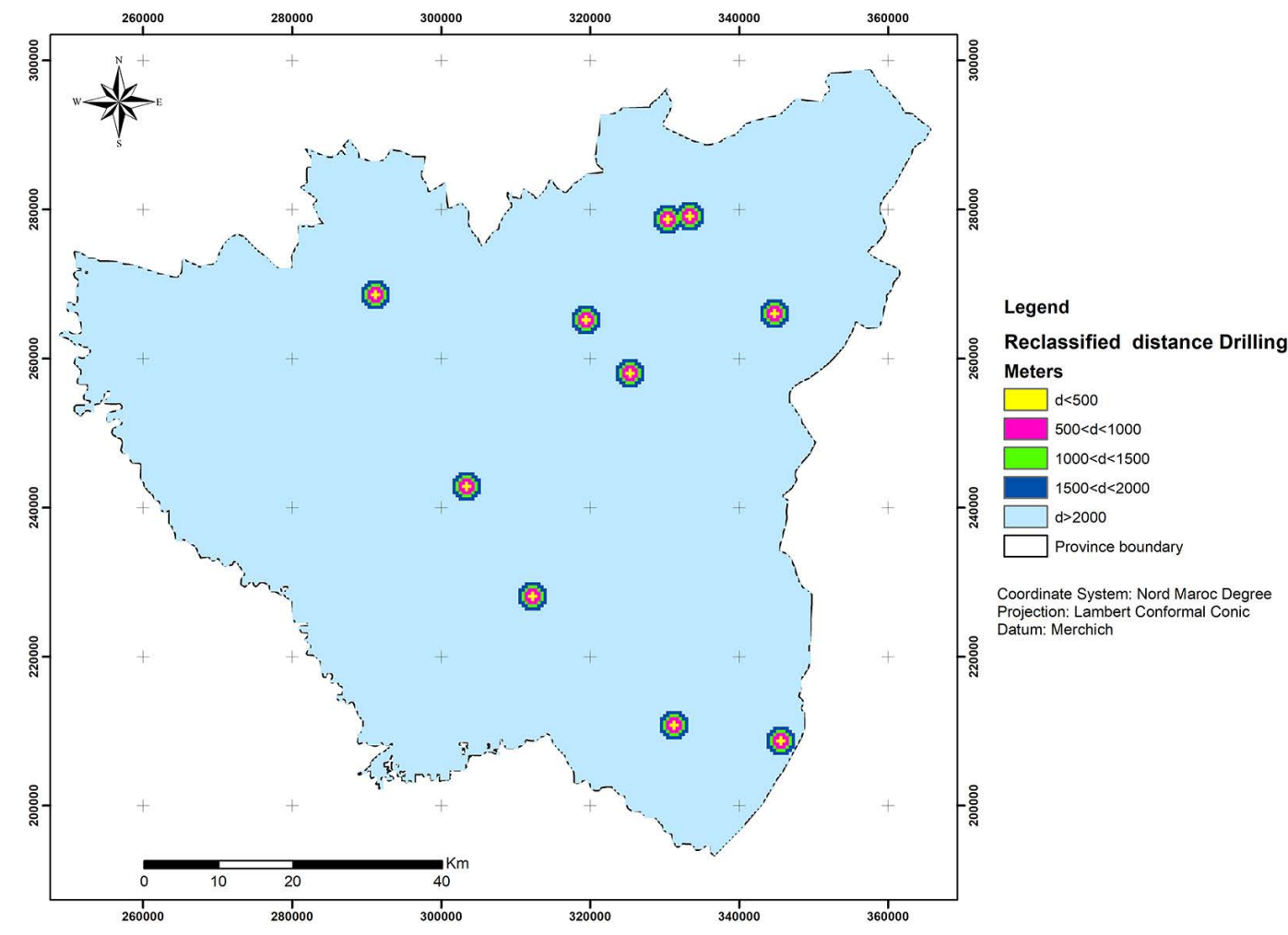

Figure 4. Map of drilling 


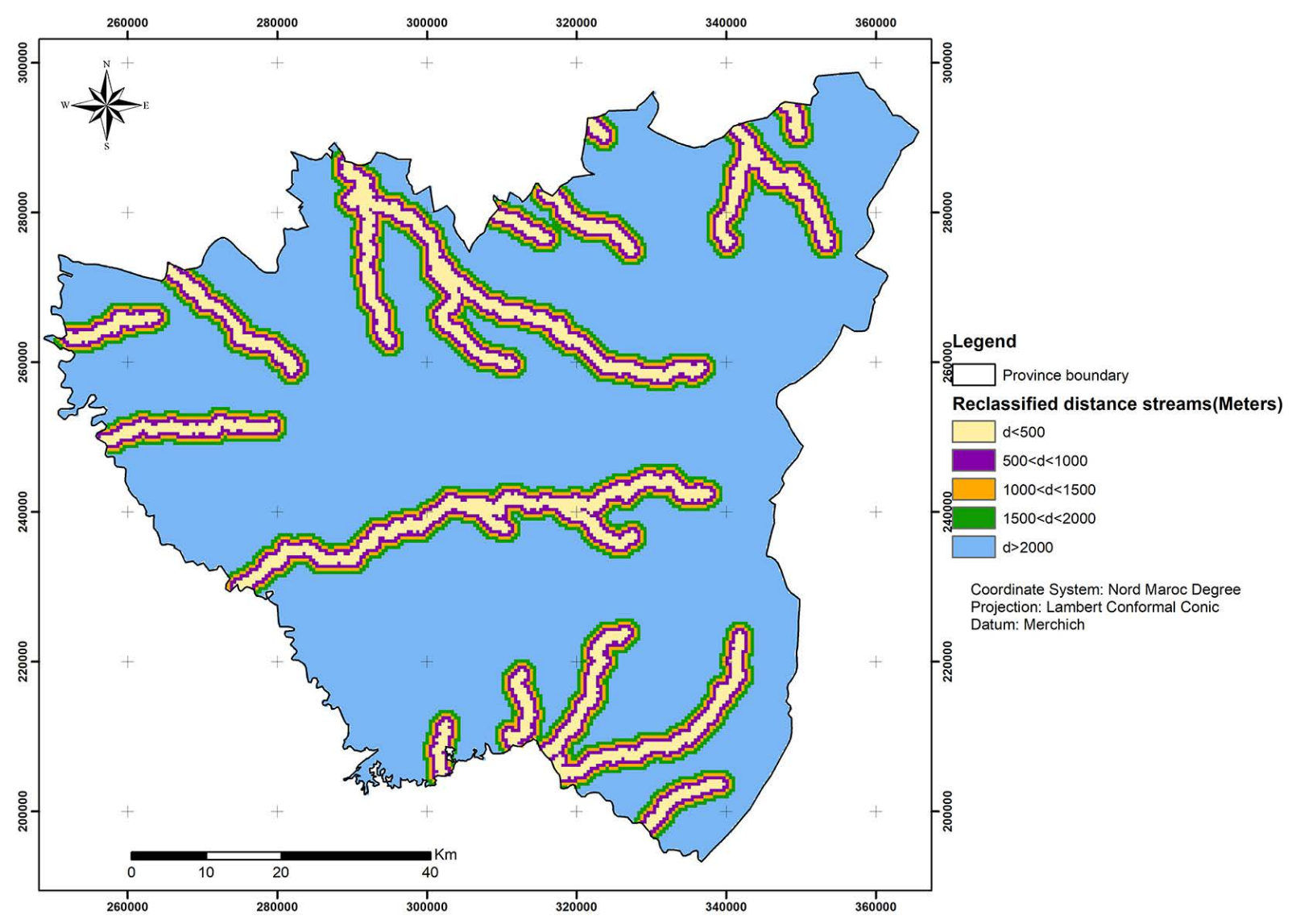

Figure 5. Map of surface water

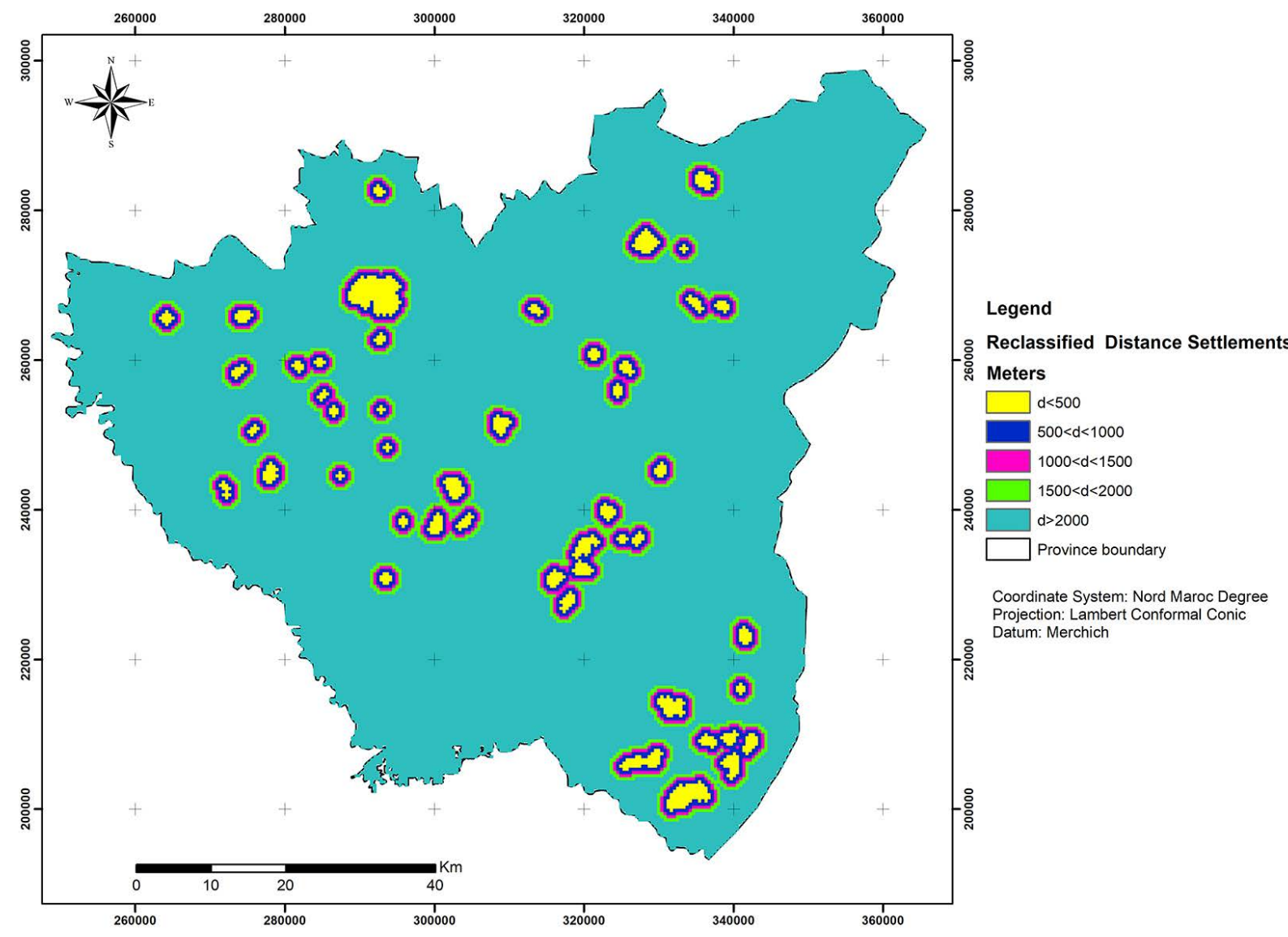

Figure 6. Map of settlements 


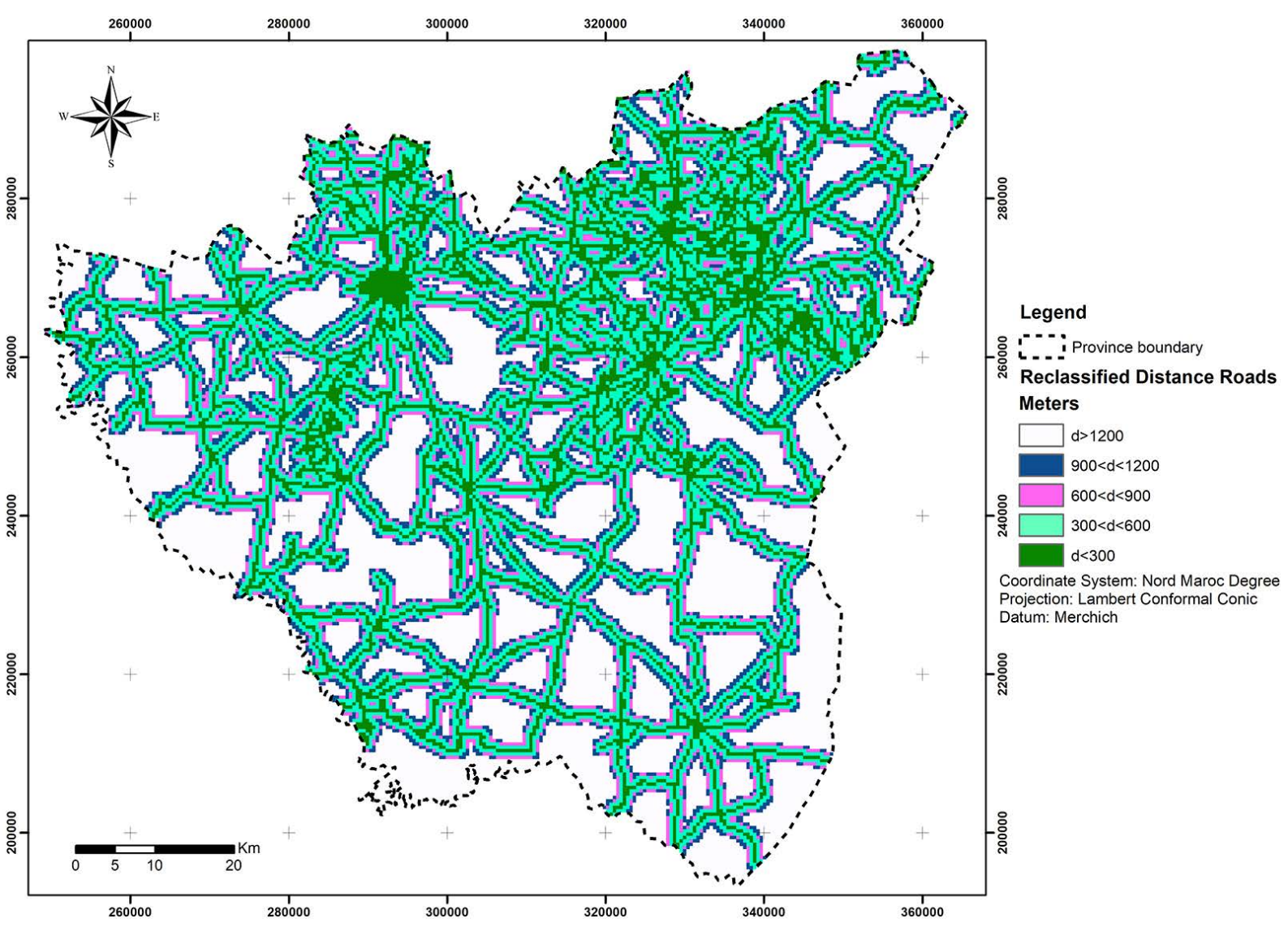

Figure 7. Map of roads

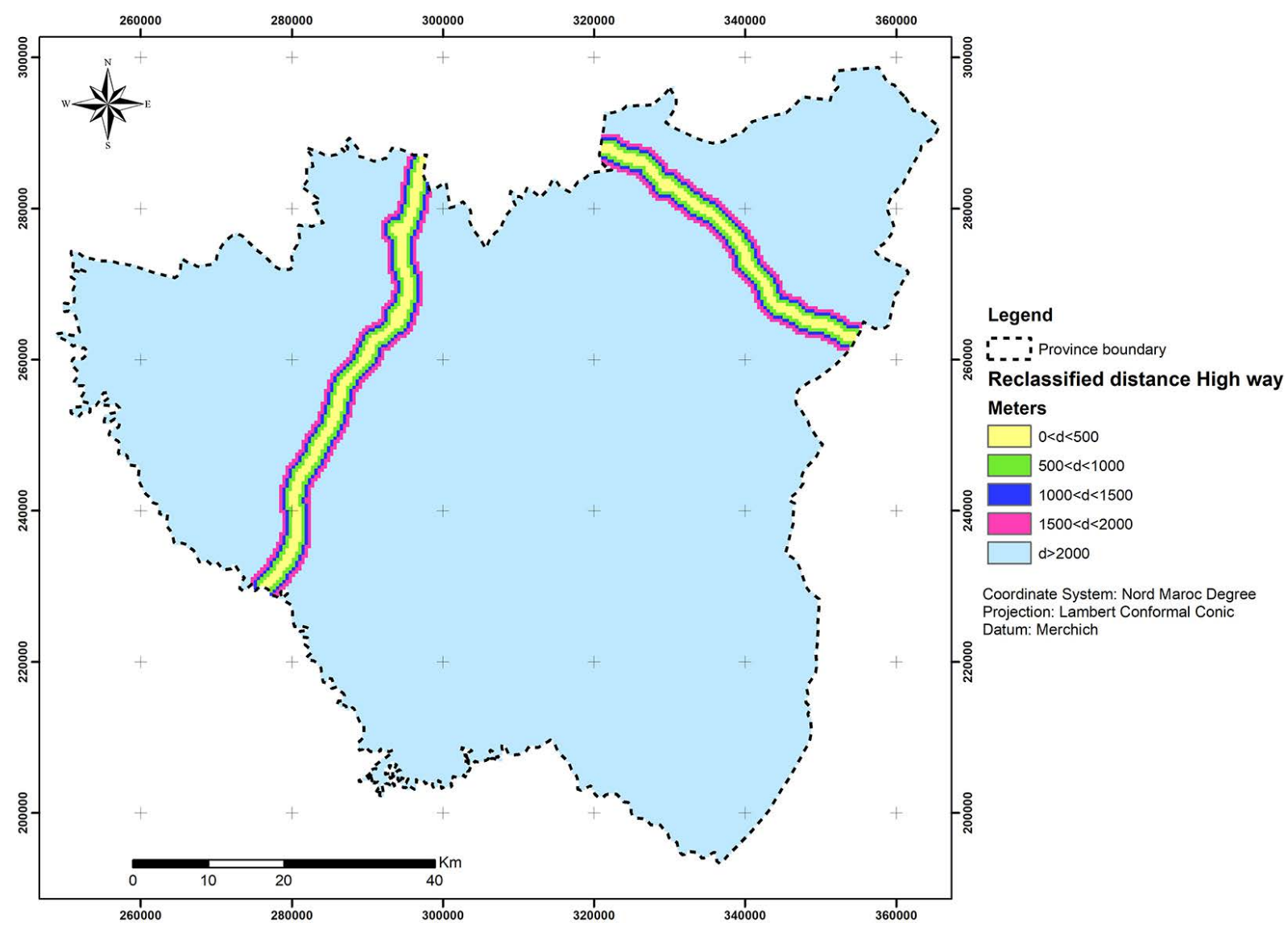

Figure 8. Map of highway 


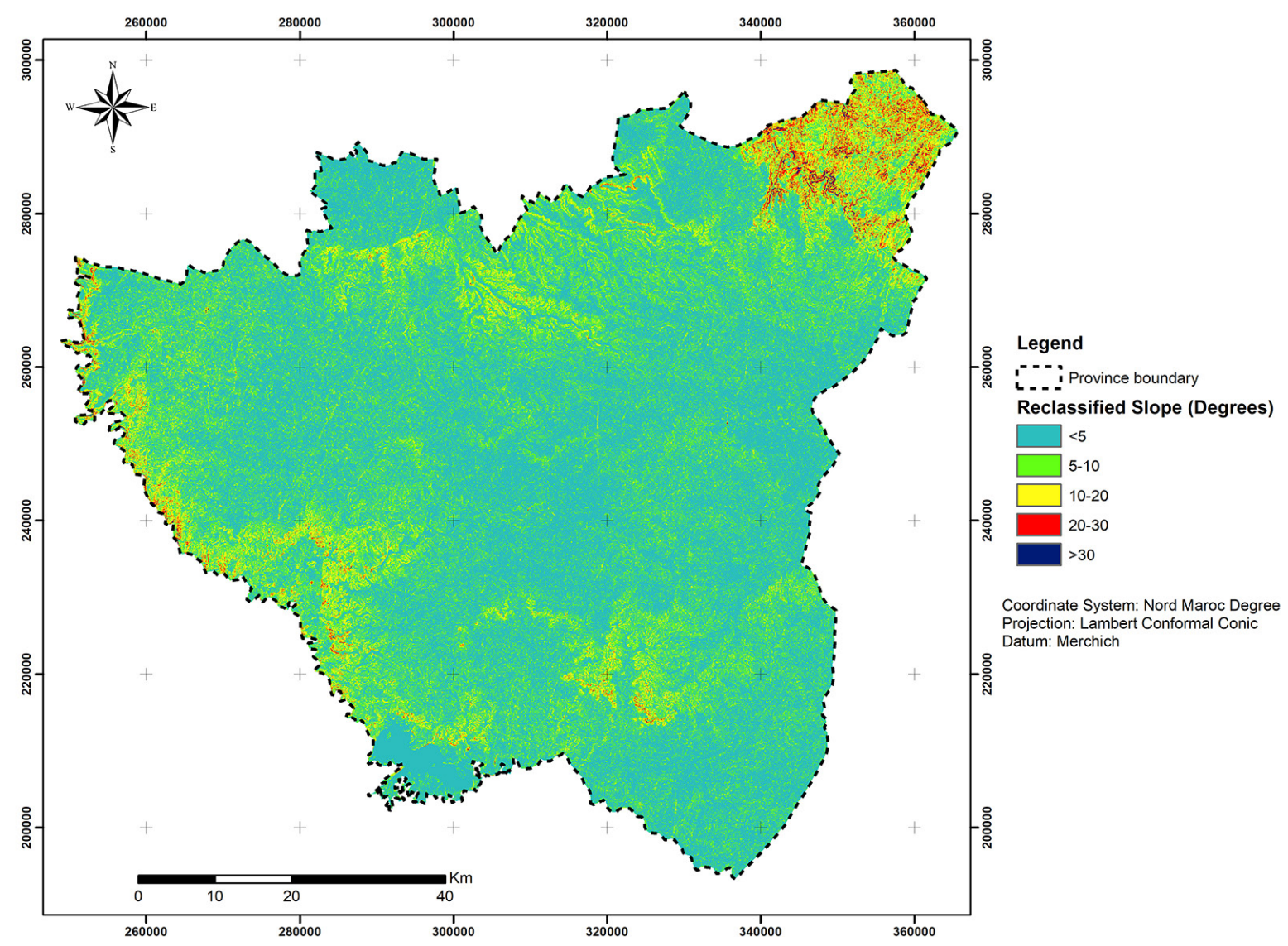

Figure 9. Map of slope

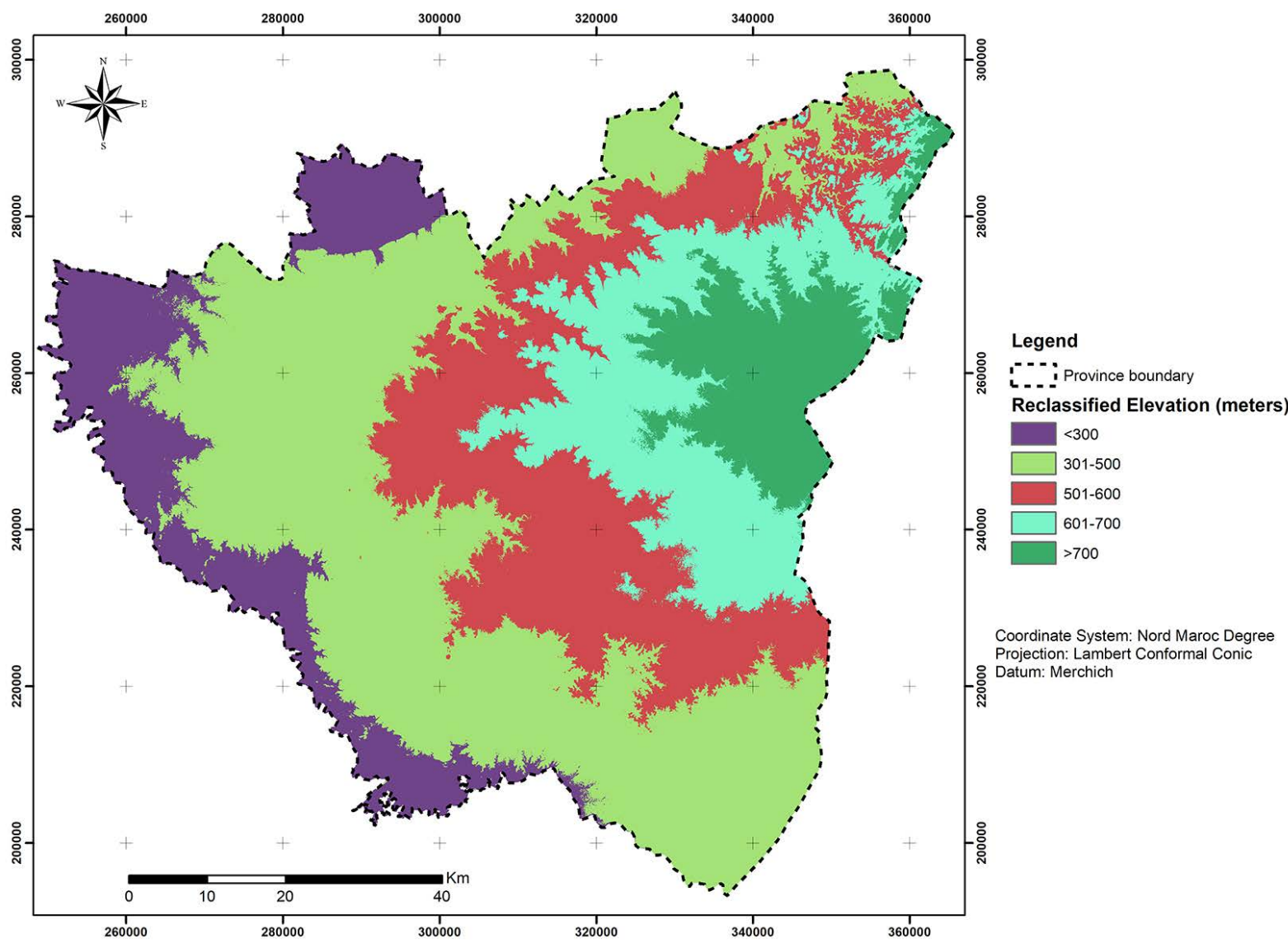

Figure 10. Map of elevation 


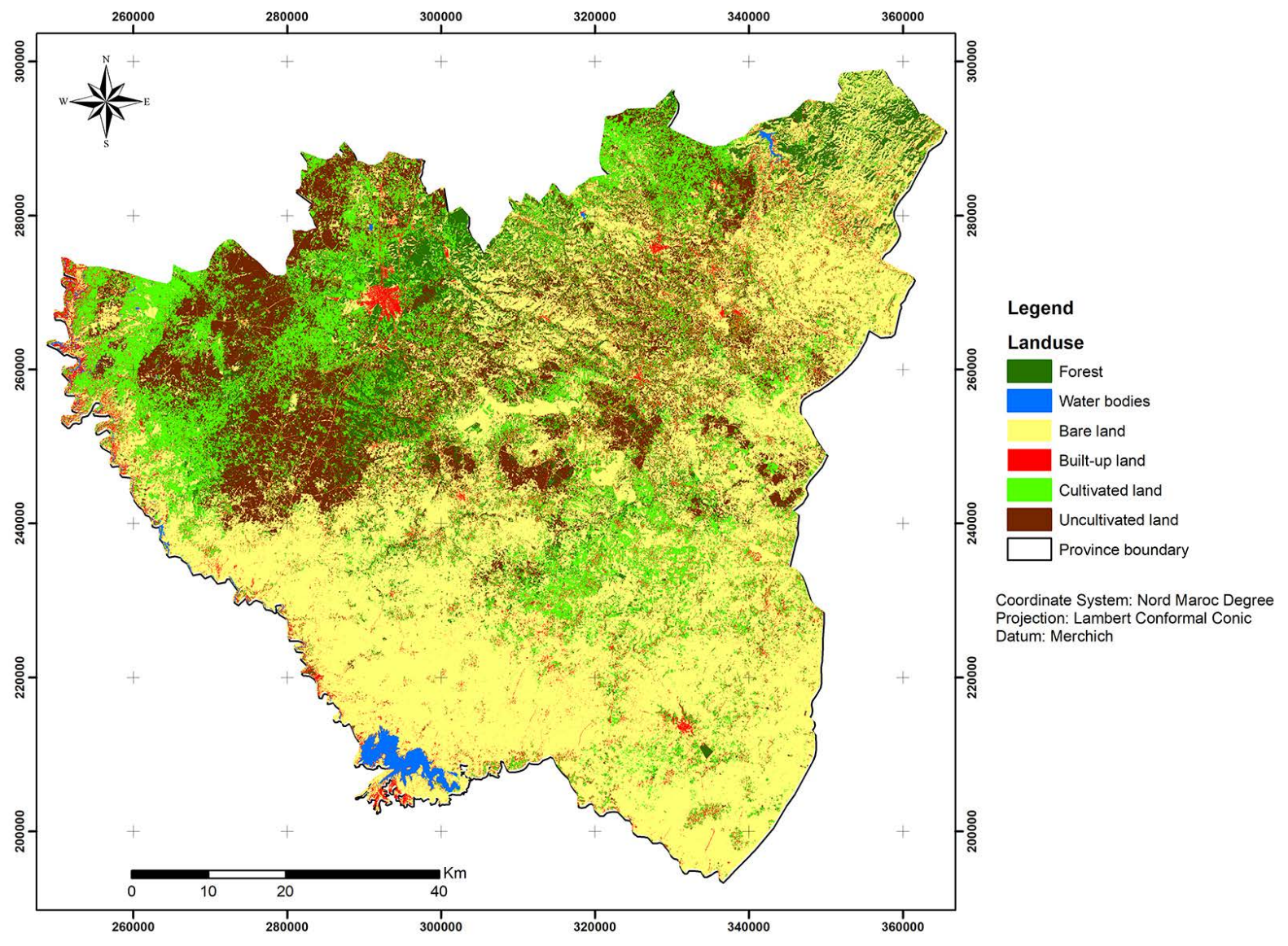

Figure 11. Map of land use

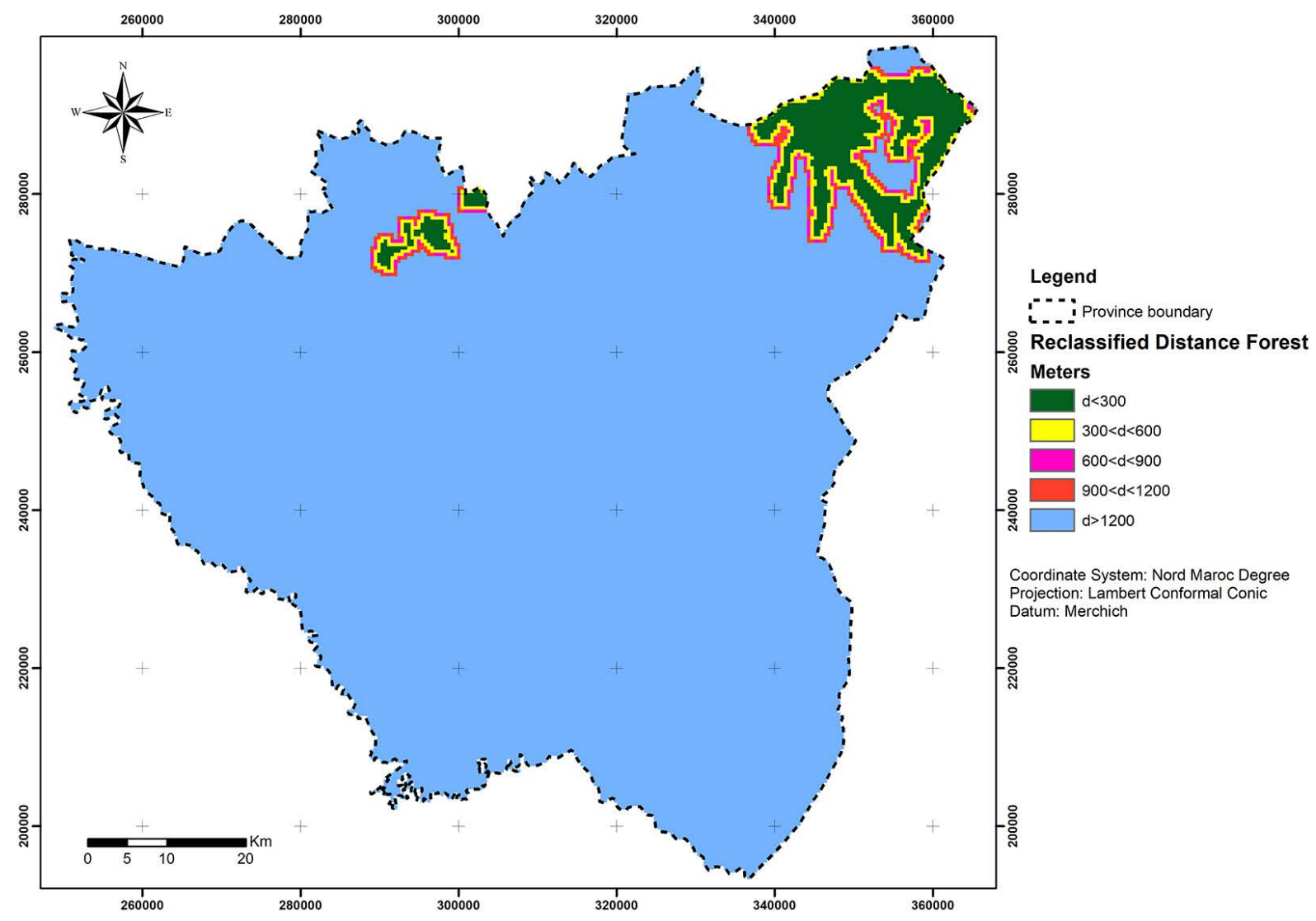

Figure 12. Map of forest 
are several rivers and dams in the province of Settat. The areas less than $500 \mathrm{~m}$ from surface water are inappropriate (rated 1), while the distance greater than $2000 \mathrm{~m}$ is very appropriate (rated 9).

- Settlements (Figure 6): The landfill site should be located more or less far from residential areas to minimize adverse effects such as odor and fire and have reasonable transportation costs (Rahmat et al., 2017). For this purpose, smaller distances between $1500 \mathrm{~m}$ and $2000 \mathrm{~m}$ were evaluated as 9.

- Road network: There is an extensive road network in the province of Settat (Figure 7). In order to minimize the cost of transport and facilitate the accessibility of the garbage vehicles to the landfill site (WangGuiqin and LiGuoxue, 2009), distances less than $300 \mathrm{~m}$ are the most adequate (noted 9), while distances greater than $1200 \mathrm{~m}$ are inappropriate (noted 1). For highways, the area farther away from the landfill, with a distance greater than $2000 \mathrm{~m}$, is the most suitable - rated 9 (Figure 8).

- Slope and elevation: A low slope and elevation are considered most economically appropriate (Güler and Yomralığlu, 2017). The slope map shows that much of the province has a gentle slope of less than $5^{\circ}$, considered very suitable (rated 9), slope more significant than $20^{\circ}$ was considered unsuitable - rated 1 (Figure 9). Similarly, elevations below 300 m were considered appropriate, while those above $700 \mathrm{~m}$ were deemed inappropriate - ranked 1 (Figure 10).

- Land use (Figure 11): When the landfill is located close to agricultural fields and water surfaces, leachate can infiltrate the soil and damage cultures (Ajibade et al., 2019). Therefore, an appropriate distance should be maintained between these surfaces and the landfill site. Bare soil was considered the most suitable site, while other locations were considered the least suitable.

- Forests (Figure 12): it is necessary to preserve the existing forests in the province of Settat. Thus, the distance greater than $1200 \mathrm{~m}$ is the most appropriate (noted 9), and a distance lesser than $300 \mathrm{~m}$ is unacceptable (noted 1).

The suitability map of landfill sites and collection and transfer centers for solid household waste shows four classes from unauthorized sites to the most suitable sites (Figure 13). In the case of the

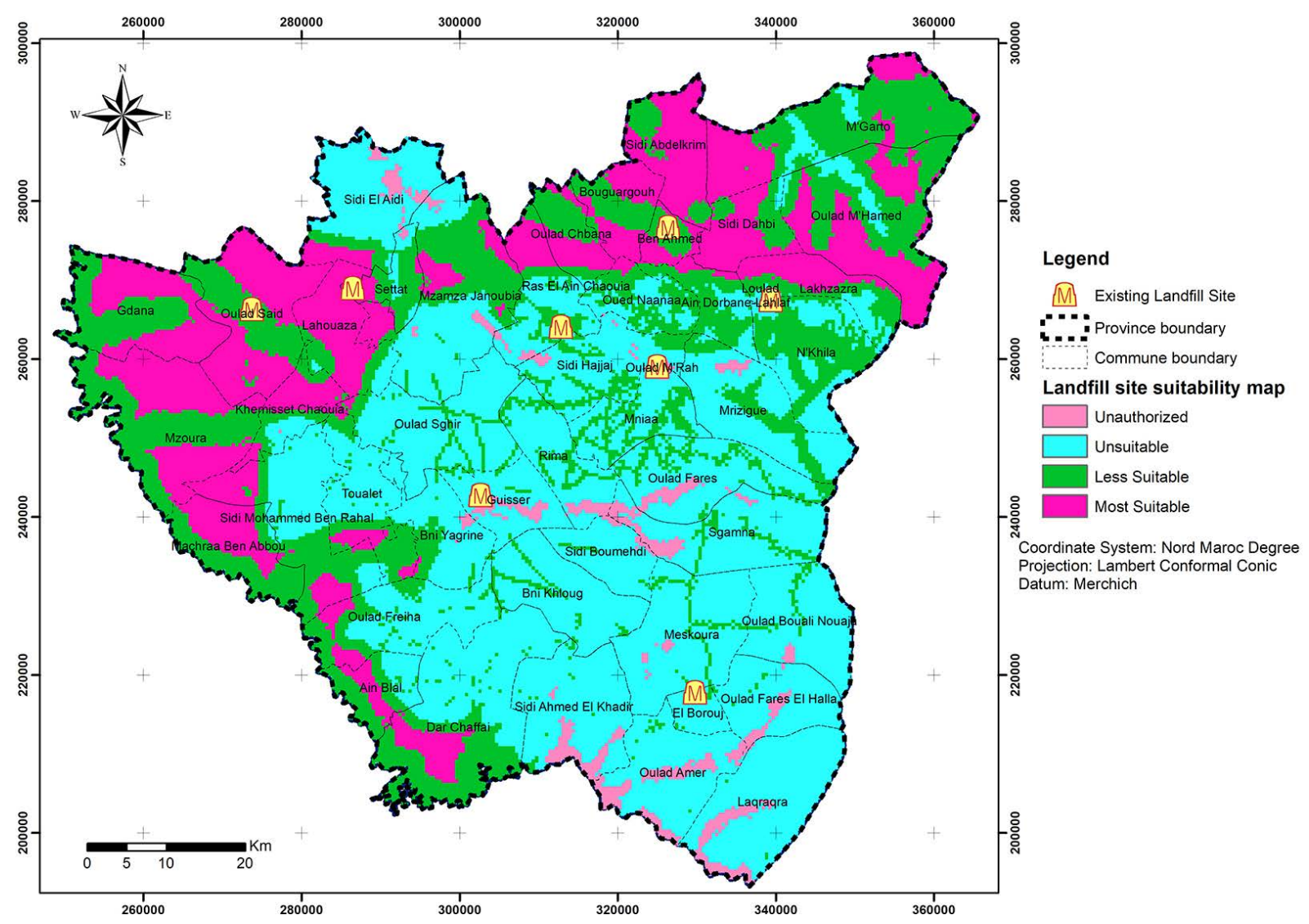

Figure 13. Suitability map 
surveyed area, $18.5 \%$ was considered suitable. The analysis of the locations of the existing landfills in the province shows that they are located on unsuitable sites, except the landfill in the commune of Settat. Therefore, this landfill can be transformed into a controlled provincial inter-communal landfill containing a recycling/recovery and composting system. This work will allow the managers to decide on the location of the sanitary landfill and the collection and transfer centers in the Settat province.

\section{CONCLUSION}

Landfill site selection is an essential process for good waste management. This choice was made by integrating geographic information system and multi-criteria evaluation techniques to improve decision-making, because it manages and organizes a large amount of geographic data for site selection. The basic principle of the AHP technique is to divide the decision problems into several smaller parts, examine each component separately, and finally integrate the elements in a coherent manner in the ArcGIS geographic information system. The present study allowed the selection of several suitable locations for installing controlled landfills in compliance with the Moroccan standards, taking into account several economic and environmental factors. A technical and financial study of landfill sizing is underway.

\section{REFERENCES}

1. Abad, P.M.S., n.d., Application AHP-PROMETHEE Technic for Landfill Site Selection on Based Assessment of Aquifers Vulnerability to Pollution: Iranian Journal of Science and Technology, p. 20.

2. Ahmed, A.E.,G. Jihane, B. Yassir, and B. Anas, 2021, The choice of optimal sites for controlled landfill using the Analytical Hierarchy Process and the Geographic Information System: A case of Oum Azza in Morocco: p. 6.

3. Ait Errouhi, A., J. Gharib, Y. Bouroumine, and A. Bahi, 2021, The choice of optimal sites for controlled landfill using the Analytical Hierarchy Process and the Geographic Information System: A case of Oum Azza in Morocco: E3S Web of Conferences, 234, no. 00066, doi:10.1051/e3sconf/202123400066.

4. Ajibade, F.O., O.O. Olajire, T.F. Ajibade, N.A. Nwogwu, K.H. Lasisi, A.B. Alo, T.A. Owolabi, and J.R. Adewumi, 2019, Combining multicriteria decision analysis with GIS for suitably siting landfills in a Nigerian state: Environmental and Sustainability Indicators, 3-4, no. 100010, doi:10.1016/j. indic.2019.100010.

5. Ali, S.A., F. Parvin, N. Al-Ansari, Q. B. Pham, A. Ahmad, M.S. Raj, D.T. Anh, L.H. Ba, and V.N. Thai, 2021, Sanitary landfill site selection by integrating AHP and FTOPSIS with GIS: a case study of Memari Municipality, India: Environmental Science and Pollution Research, 28(6), 7528-7550, doi:10.1007/s11356-020-11004-7.

6. Anane, M., H. Kallali, S. Jellali, and M. Ouessar, 2008, Ranking suitable sites for Soil Aquifer Treatment in Jerba Island (Tunisia) using remote sensing, GIS and AHP-multicriteria decision analysis: International Journal of Water, 4(1/2), p. 121, doi:10.1504/IJW.2008.018151.

7. Benezzine, G., Z. Abdeljalil, and K. Yahya, 2021, Use of GIS for Digital Mapping and Spatial Analysis of Landfills: Case of the Settat Province in Morocco: Ecological Engineering \& Environmental Technology, 22(3), 1-10, doi:10.12912/27197050/134868.

8. Chabuk, A., N. Al-Ansari, H.M. Hussain, S. Knutsson, and R. Pusch, 2016, Landfill site selection using geographic information system and analytical hierarchy process: A case study Al-Hillah Qadhaa, Babylon, Iraq: Waste Management \& Research, 34, (5), 427-437, doi:10.1177/0734242X16633778.

9. Donevska, K.R., P.V. Gorsevski, M. Jovanovski, and I. Peševski, 2012, Regional non-hazardous landfill site selection by integrating fuzzy logic, AHP and geographic information systems: Environmental Earth Sciences, 67(1), 121-131, doi:10.1007/ s12665-011-1485-y.

10. Gbanie, S.P., P.B. Tengbe, J.S. Momoh, J. Medo, and V.T.S. Kabba, 2013, Modelling landfill location using Geographic Information Systems (GIS) and Multi-Criteria Decision Analysis (MCDA): Case study Bo, Southern Sierra Leone: Applied Geography, 36, 3-12, doi:10.1016/j.apgeog.2012.06.013.

11. Ghobadi, M.H., M. Taheri, and K. Taheri, 2017, Municipal solid waste landfill siting by using analytical hierarchy process (AHP) and a proposed karst vulnerability index in Ravansar County, west of Iran: Environmental Earth Sciences, 76(2), p. 68, doi:10.1007/s12665-017-6392-4.

12. Güler, D., and T. Yomralığlu, 2017, Alternative suitable landfill site selection using analytic hierarchy process and geographic information systems: a case study in Istanbul: Environmental Earth Sciences, 76(20), p. 678, doi:10.1007/s12665-017-7039-1.

13. Kebede, Y.S., M.M. Alene, and N.T. Endalemaw, 2021, Urban landfill investigation for managing the negative impact of solid waste on environment using geospatial technique. A case study of Assosa town, Ethiopia: Environmental Challenges, 4, no. 100103, doi:10.1016/j.envc.2021.100103. 
14. Langa, C., J. Hara, J. Wang, K. Nakamura, N. Watanabe, and T. Komai, 2021, Dynamic evaluation method for planning sustainable landfills using GIS and multi-criteria in areas of urban sprawl with landuse conflicts: PLOS ONE, 16(8), no. e0254441, doi:10.1371/journal.pone.0254441.

15. Mahmood, K.W., B.O. Khzr, R.M. Othman, A. Rasul, S.A. Ali, and G.R.F. Ibrahim, 2021, Optimal site selection for landfill using the boolean-analytical hierarchy process: Environmental Earth Sciences, 80(5), p. 173, doi:10.1007/s12665-021-09501-0.

16. Majid, M., and B.A. Mir, 2021, Landfill site selection using GIS based multi criteria evaluation technique. A case study of Srinagar city, India: Environmental Challenges, 3, no. 100031, doi:10.1016/j. envc.2021.100031.

17. Mortazavi Chamchali, M., A. Mohebbi Tafreshi, and G. Mohebbi Tafreshi, 2021, Utilizing GIS linked to AHP for landfill site selection in Rudbar County of Iran: GeoJournal, 86(1), 163-183, doi:10.1007/ s10708-019-10064-8.

18. Rahmat, Z.G., M.V. Niri, N. Alavi, G. Goudarzi, A.A. Babaei, Z. Baboli, and M. Hosseinzadeh, 2017, Landfill site selection using GIS and AHP: a case study: Behbahan, Iran: KSCE Journal of Civil Engineering, 21(1), 111-118, doi:10.1007/s12205-016-0296-9.

19. Saaty, T.L., 1990, How to make a decision: The analytic hierarchy process: European Journal of Operational Research, 48(1), 9-26, doi:10.1016/0377-2217(90)90057-I.

20. Sisay, G., S.L. Gebre, and K. Getahun, 2021, GISbased potential landfill site selection using MCDMAHP modeling of Gondar Town, Ethiopia: African Geographical Review, 40(2), 105-124, doi:10.108 0/19376812.2020.1770105.

21. WangGuiqin, Q., and C. LiGuoxue, 2009, Landfill site selection using spatial information technologies and AHP: A case study in Beijing, China: Journal of Environmental Management, p. 8.

22. Yildirim, V., T. Memisoglu, S. Bediroglu, and H.E. Colak, 2018, Municipal solid waste landfill site selection using Multi-Criteria Decision Making and GIS: case study of Bursa province, 2: Journal of Environmental Engineering and Landscape Management, 26(2), 107-119, doi:10.3846/16486897. 2017.1364646. 